University of Nebraska - Lincoln

DigitalCommons@University of Nebraska - Lincoln

USDA National Wildlife Research Center - Staff Publications
U.S. Department of Agriculture: Animal and Plant Health Inspection Service

January 2007

\title{
USING A COMMERCIALLY AVAILABLE ENZYME IMMUNOASSAY TO QUANTIFY TESTOSTERONE IN AVIAN PLASMA
}

\author{
Brian E. Washburn \\ brian.e.washburn@aphis.usda.gov \\ Joshua J. Millspaugh \\ University of Missouri, Columbia, MO \\ Dana L. Morris \\ University of Missouri, Columbia, MO \\ John H. Schulz \\ Missouri Department of Conservation, Resource Science Center \\ John Faaborg \\ University of Missouri, Columbia
}

U.S. Department of Agriculture, Wildlife Services, National Wildlife Research Center,

Follow this and additional works at: https://digitalcommons.unl.edu/icwdm_usdanwrc

Part of the Environmental Sciences Commons

Washburn, Brian E.; Millspaugh, Joshua J.; Morris, Dana L.; Schulz, John H.; and Faaborg, John, "USING A COMMERCIALLY AVAILABLE ENZYME IMMUNOASSAY TO QUANTIFY TESTOSTERONE IN AVIAN PLASMA" (2007). USDA National Wildlife Research Center - Staff Publications. 522.

https://digitalcommons.unl.edu/icwdm_usdanwrc/522

This Article is brought to you for free and open access by the U.S. Department of Agriculture: Animal and Plant Health Inspection Service at DigitalCommons@University of Nebraska - Lincoln. It has been accepted for inclusion in USDA National Wildlife Research Center - Staff Publications by an authorized administrator of DigitalCommons@University of Nebraska - Lincoln. 


\title{
USING A COMMERCIALLY AVAILABLE ENZYME IMMUNOASSAY TO QUANTIFY TESTOSTERONE IN AVIAN PLASMA
}

\author{
Brian E. Washburn ${ }^{1,5}$, Joshua J. Millspaugh ${ }^{2}$, Dana L. Morris ${ }^{2}$, John H. Schulz ${ }^{3}$, \\ AND JOHN FAABORG ${ }^{4}$ \\ ${ }^{1}$ U.S. Department of Agriculture, Wildlife Services, National Wildlife Research Center, 6100 Columbus Avenue, \\ Sandusky, $\mathrm{OH} 44870$ \\ ${ }^{2}$ Department of Fisheries and Wildlife Sciences, University of Missouri, 302 A-BNR Building, Columbia, \\ MO 65211 \\ ${ }^{3}$ Missouri Department of Conservation, Resource Science Center, 1110 South College Avenue, Columbia, \\ MO 65201 \\ ${ }^{4}$ Division of Biological Sciences, University of Missouri, Tucker Hall, Columbia, MO 65211
}

\begin{abstract}
Using a commercially available testosterone enzyme immunoassay (EIA), we developed and validated an assay procedure for determining testosterone levels in small-volume $(20 \mu \mathrm{L})$ avian plasma samples. We evaluated this EIA's utility by measuring plasma testosterone levels in Mourning Doves (Zenaida macroura), White-eyed Vireos (Vireo griseus), Red-eyed Vireos (Vireo olivaceus), and Indigo Buntings (Passerina cyanea). Standard biochemical validations (e.g., parallelism, recovery of exogenous testosterone) demonstrated that the assay accurately and precisely measured testosterone in avian plasma. We compared plasma testosterone levels in males and females of all four species and Indigo Buntings in various reproductive stages to physiologically validate the assay's ability to determine biologically important changes in testosterone levels. Plasma testosterone levels were higher in males compared to females in three of four species. Prebreeding and breeding male Indigo Buntings had higher circulating testosterone levels than postbreeding males. Testosterone levels in our study were similar to reported values for other passerine species using radioimmunoassay procedures. Our results suggest that this EIA procedure is very effective for determining testosterone levels in small-volume avian plasma samples and is sensitive enough to detect biologically important changes in the gonadal activity of birds. Thus, this assay has considerable utility for measuring testosterone in small birds $(<15 \mathrm{~g})$, from which only small volumes of plasma $(20 \mu \mathrm{L})$ can be collected.
\end{abstract}

Key words: Columbiformes, enzyme immunoassay, Passeriformes, plasma, testosterone.

Uso de un Inmunoensayo Enzimático de Testosterona Disponible Comercialmente

Manuscript received 9 February 2006; accepted 17 August 2006.

${ }_{5}^{5}$ E-mail: brian.e.washburn@aphis.usda.gov para Cuantificar la Testosterona en el Plasma de las Aves

Resumen. Empleando un inmunoensayo enzimático de testosterona disponible comercialmente, desarrollamos y validamos un procedimiento para determinar los niveles de testosterona en volúmenes pequeños $(20 \mu \mathrm{L})$ de muestras de plasma de aves. Evaluamos la utilidad de este procedimiento midiendo los niveles plasmáticos de testosterona en Zenaida macroura, Vireo griseus, Vireo olivaceus y Passerina cyanea. Validaciones bioquímicas estándar (e.g., paralelismo, recuperación de testosterona exógena) demostraron que el ensayo mide la testosterona plasmática con exactitud y precisión. Para validar fisiológicamente la habilidad del ensayo para detectar cambios biológicamente importantes en los niveles de testosterona, comparamos los niveles plasmáticos de testosterona entre machos y hembras de las cuatro especies y entre varios estadíos reproductivos de $P$. cyanea. Los niveles plasmáticos de testosterona fueron mayores en los machos que en las hembras en tres de las cuatro especies. Los individuos pre-reproductivos y los machos reproductivos de $P$. cyanea presentaron niveles circulantes de testosterona mayores que los machos post-reproductivos. Los niveles de testosterona documentados por nuestro estudio fueron similares a los reportados para otras especies de aves paserinas mediante radioinmunoensayos. Nuestros resultados sugieren que el inmunoensayo enzimático de testosterona es un procedimiento muy efectivo para determinar los niveles de testosterona en las aves a partir de muestras de plasma de volumen pequeño, y que éste es lo suficientemente sensible como para detectar cambios biológicamente importantes en la actividad de las gónadas de las aves. Por lo tanto, este ensayo presenta una utilidad considerable para medir la testosterona en aves pequeñas $(<15 \mathrm{~g})$, para las cuales sólo pueden colectarse volúmenes pequeños de plasma $(20 \mu \mathrm{L})$. 
Testosterone is a steroid hormone that plays a significant role in the reproductive function of many vertebrates, including birds (Hadley 1996). Circulating levels of testosterone affect territorial and mating behaviors of male birds, including aggressive behaviors (Wingfield et al. 1987, Chandler et al. 1994), production of song (Schwabl and Kriner 1991), intensity of mate guarding (Saino and Møller 1995), male parental care involvement (Lynn et al. 2005), and male mating success (Silverin 1980, Ketterson et al. 1996, Garamszegi et al. 2005).

Gonadal activity in birds is typically assessed by measuring testosterone levels in blood. However, obtaining the amount of blood necessary for testosterone analysis is problematic in small birds. Due to the small volume of blood samples, few testosterone assays are available to quantify plasma testosterone in small birds, particularly if serial samples are required. A review of the recent avian and endocrinology literature suggests that the most commonly used assay to determine testosterone in plasma is the one described by Wingfield and Farner (1975). Although this assay is very effective for determining plasma testosterone levels in smallvolume samples, the assay procedure is complex and the radioimmunoassay (RIA) is not commercially produced. Radioimmunoassay procedures have drawbacks, such as radioactive materials that require special licenses to use, the need for specialized and expensive detection equipment, and the production of hazardous waste materials (Lee et al. 1995, Graham et al. 2001). The development of simpler enzyme immunoassay (EIA) procedures that use commercially available EIA kits might provide an alternative. Enzyme immunoassays do not require radioactive materials and thus provide an economical and often preferable alternative method for zoo and field situations (Lee et al. 1995, Graham et al. 2001). In this study, we report the biochemical and physiological validation of a commercially available testosterone EIA capable of utilizing small avian plasma samples.

We compared plasma testosterone levels in males and females of four bird species and Indigo Buntings (Passerina cyanea) in various reproductive stages to physiologically validate the assay's ability to determine biologically important changes in plasma testosterone levels in birds. Our objectives were to: (1) develop an enzyme immunoassay procedure using a commercially available kit for determining testosterone levels from small-volume $(20 \mu \mathrm{L})$ avian plasma samples, and (2) validate the assay for use in four avian species.

\section{METHODS}

\section{STUDY AREAS AND SPECIES}

We used the Mourning Dove (Zenaida macroura), White-eyed Vireo (Vireo griseus), Red-eyed Vireo (Vireo olivaceus), and Indigo Bunting (Passerina cyanea) in our study. We captured Mourning Doves using modified Kniffin traps (Reeves et al. 1968) baited with white proso millet near Columbia, Missouri $\left(38^{\circ} 54^{\prime} \mathrm{N}, 92^{\circ} 18^{\prime} \mathrm{W}\right)$, in November 2001. Within 2 hr of capture, we transported the Mourning
Doves to the University of Missouri's T. S. Baskett Wildlife Research and Education Center, located near Ashland, Missouri $\left(38^{\circ} 45^{\prime} \mathrm{N}, 92^{\circ} 12^{\prime} \mathrm{W}\right)$. Mourning Doves were individually housed in $1.8 \times 1.8 \times$ $1.8 \mathrm{~m}$ outdoor cages (Mong et al. 2002). We provided a wild-bird seed mixture (sorghum grains, wheat, crimped corn, oats, and sunflower seeds) and water ad libitum. We collected blood samples from individually housed male and female after-hatchingyear (AHY) Mourning Doves during 07:00-09:00 on 12 July 2002.

We captured White-eyed Vireos, Red-eyed Vireos, and Indigo Buntings in oak-hickory forests in the Current River Conservation Area, Reynolds County, southeastern Missouri $\left(37^{\circ} 8^{\prime} \mathrm{N}, 91^{\circ} 3^{\prime} \mathrm{W}\right)$. We captured AHY postbreeding male and female Whiteeyed and Red-eyed Vireos as they dispersed from their breeding territories in forested areas from 06:00 to 12:00 CST during 17-24 July 2002. After-hatchingyear male and female Indigo Buntings were captured using song playbacks and mist nets or by mist-netting at their nests while they were provisioning nestlings from 06:00 to 12:00 CST during May-August 2002.

\section{BLOOD COLLECTION}

We collected an initial blood sample (30-50 $\mu \mathrm{L})$ from each individual within 2-4 min of capture using heparinized hematocrit microcapillary tubes after puncture of the brachial vein using a 26-gauge needle. We kept blood samples on ice for approximately 4-5 hr and then centrifuged them at $2500 \mathrm{~g}$ for $10 \mathrm{~min}$. Recovered plasma (volumes ranged from 12 to $35 \mu \mathrm{L}$ ) was transferred to microcentrifuge tubes and stored at $-84^{\circ} \mathrm{C}$ until assay.

\section{ENZYME IMMUNOASSAY PROCEDURES AND BIOCHEMICAL VALIDATION}

We measured plasma testosterone concentrations in each individual blood sample using a commercially available salivary testosterone enzyme immunoassay kit (Cat. \#1-1402, Salimetrics LLC, State College, Pennsylvania). We followed the manufacturer's protocol for the EIA. All plasma samples were diluted $1: 10$ with assay dilutant (e.g., $15 \mu \mathrm{L}$ of plasma into $135 \mu \mathrm{L}$ of assay dilutant) for our assays. We conducted standard validations including parallelism and recovery of exogenous testosterone (Jeffcoate 1981, Grotjan and Keel 1996, O'Fegan 2000) on two pooled plasma samples (low [i.e., expected lower values] and high [i.e., expected higher values]; each pool consisted of plasma from three individuals) from each species to confirm the assay was accurately and precisely measuring testosterone in avian plasma. Parallelism ensures the assay maintains linearity under dilution, and recovery of exogenous testosterone verifies accurate measurement throughout the working range of the assay (Jeffcoate 1981).

\section{STATISTICAL ANALYSES}

We used Mann-Whitney $U$-tests to determine whether differences in plasma testosterone concentrations existed between sexes for each species (Zar 1996). We compared plasma testosterone levels of prebreeding, breeding, and postbreeding male AHY Indigo Bunt- 
(A) Mouming Doves

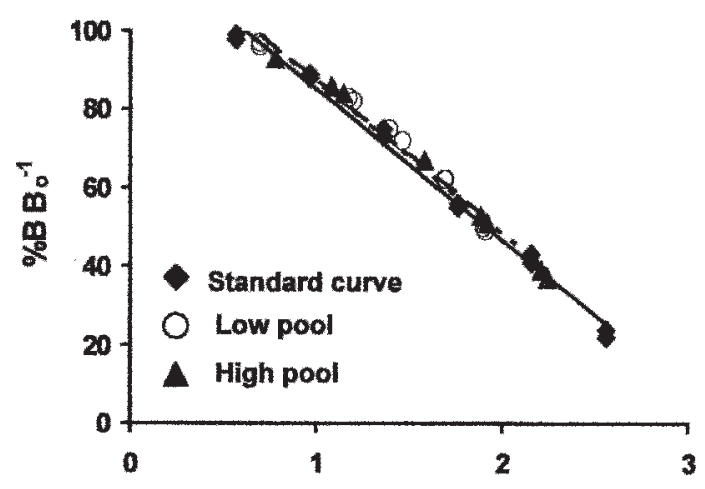

(C) Red-eyed Vireos

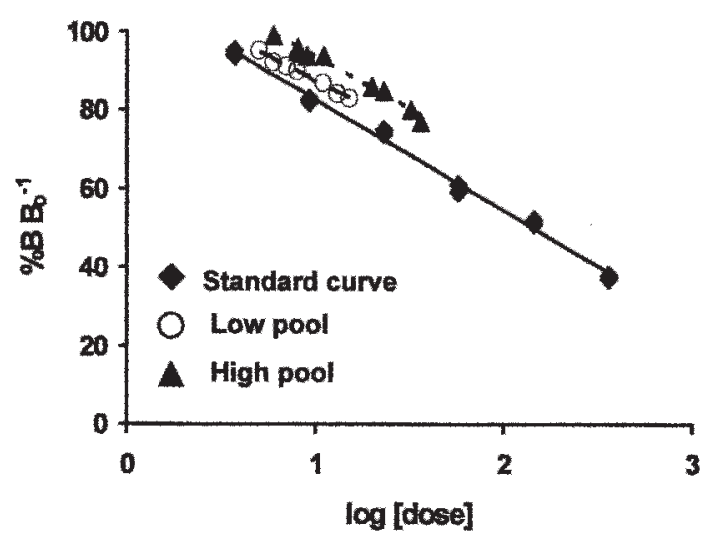

(B) White-eyed Vireos

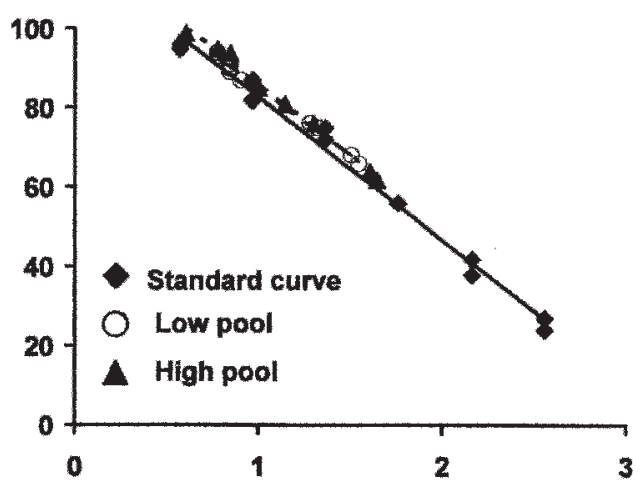

(D) Indigo Buntings

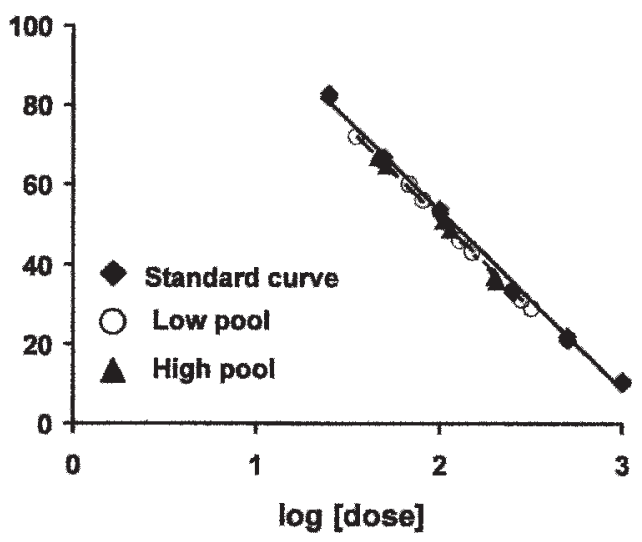

FIGURE 1. Parallelism of plasma testosterone results for four bird species. Curves of percent binding of horseradish peroxidase-labeled testosterone $\left(\% \mathrm{~B} \mathrm{~B}_{\mathrm{o}}{ }^{-1}\right)$ versus serially diluted (log-transformed doses of 1:1, $1: 2,1: 4,1: 8$, and 1:16) low pool (expected lower values; $n=2$ per species) and high pool (expected higher values; $n=2$ per species) plasma samples from free-ranging after-hatching-year (A) wild Mourning Doves in captivity, (B) postbreeding White-eyed Vireos, (C) postbreeding Red-eyed Vireos, and (D) breeding Indigo Buntings were parallel (test of equal slopes, all $P>0.16$ ) to testosterone standard curves (log-transformed doses of 3.7 to $\left.360 \mathrm{pg} \mathrm{mL}^{-1}\right)$.

ings using a Kruskal-Wallis test and associated means comparisons tests (Zar 1996). We used tests for equal slopes (parallelism) to determine if logtransformed curves of serially diluted low and high pooled plasma samples from each species were parallel to log-transformed testosterone standard curves (Neter et al. 1990). We used SAS (SAS Institute 1990) to perform all statistical analyses and considered test results significant at $P \leq 0.05$.

\section{RESULTS}

\section{ENZYME IMMUNOASSAY}

\section{BIOCHEMICAL VALIDATION}

We successfully used the Salimetrics salivary testosterone EIA to quantify plasma testosterone in
Mourning Doves, White-eyed Vireos, Red-eyed Vireos, and Indigo Buntings. Serial dilutions (1:1, $1: 2,1: 4,1: 8$, and 1:16) of two pooled plasma samples from each species yielded displacement curves that were parallel (test of equal slopes, all $P>0.16$ ) to the standard testosterone curve (Fig. 1). Mean recovery of exogenous testosterone (range $=23-144 \mathrm{pg} \mathrm{mL}^{-1}$; levels chosen to correspond with expected plasma testosterone levels from actual samples) added to low and high pooled plasma samples and average intraassay variation $(n=10)$ are presented for each species in Table 1. Acceptable recovery of exogenous testosterone (within 90\%-110\%) and demonstration of parallelism suggests that nothing in the plasma interfered with the accuracy of the assay (i.e., no sample matrix effects; Jeffcoate 1981, Grotjan and 
TABLE 1. Quantitative recovery of exogenous testosterone and intra-assay coefficient of variation (CV) for pooled plasma samples with low and high levels of endogenous testosterone from four avian species using the Salimetrics salivary testosterone enzyme immunoassay (Cat. \#1-1402). Exogenous testosterone was added to six replicates from each pooled plasma sample. Average intra-assay $\mathrm{CV}$ was calculated from randomly chosen samples $(n=10)$.

\begin{tabular}{lcc}
\hline \hline \multicolumn{1}{c}{ Species and sample } & $\begin{array}{c}\text { Quantitative recovery } \\
\text { (Mean } \% \pm \text { SE) }\end{array}$ & $\begin{array}{c}\text { Intra-assay CV } \\
\text { (Mean \% } \pm \text { SE) }\end{array}$ \\
\hline $\begin{array}{l}\text { Mourning Dove (Zenaida macroura) } \\
\text { Low pool }\end{array}$ & $93.9 \pm 4.9$ & $7.1 \pm 1.9$ \\
$\quad$ High pool & $94.2 \pm 2.1$ & $5.8 \pm 1.4$ \\
White-eyed Vireo (Vireo griseus) & & \\
$\quad$ Low pool & $100.6 \pm 2.3$ & $5.8 \pm 1.4$ \\
$\quad$ High pool & $101.7 \pm 7.5$ & $6.0 \pm 1.4$ \\
Red-eyed Vireo (Vireo olivaceus) & & \\
$\quad$ Low pool & $102.6 \pm 4.9$ & $7.3 \pm 2.1$ \\
$\quad$ High pool & $91.2 \pm 2.2$ & $5.9 \pm 1.1$ \\
Indigo Bunting (Passerina cyanea) & & \\
$\quad$ Low pool & $92.8 \pm 3.2$ & $7.6 \pm 1.4$ \\
$\quad$ High pool & $95.5 \pm 3.4$ & $7.3 \pm 2.0$ \\
\hline
\end{tabular}

Keel 1996, O’Fegan 2000). Interassay variation for seven assays was $10.5 \%$. The manufacturer's crossreactivity of the testosterone antibody was $100 \%$ with testosterone, $1.2 \%$ with androstenedione, and $<1 \%$ for other steroids. The sensitivity of this assay was $15 \mathrm{pg} \mathrm{mL}^{-1}$.

\section{PHYSIOLOGICAL RESULTS}

Plasma testosterone levels were higher in male Mourning Doves $(U=9.3, P<0.001)$, Red-eyed Vireos $(U=6.1, P=0.01)$, and Indigo Buntings ( $U$ $=11.7, P<0.001)$ compared to females of the same species and breeding status (Fig. 2). In contrast, plasma testosterone levels of postbreeding male and female White-eyed Vireos were similar $(U=0.02, P$ $=0.9$; Fig. 2).

Plasma testosterone levels of male Indigo Buntings varied relative to breeding status $(H=4.4, \mathrm{df}=2, P$ $=0.03)$. Prebreeding and breeding male Indigo Buntings had elevated plasma testosterone levels compared to postbreeding males (Fig. 3).

\section{DISCUSSION}

Our findings suggest the Salimetrics salivary testosterone EIA used in this study is effective for determining testosterone levels in small-volume plasma samples of four bird species. The performance characteristics (recovery of exogenous testosterone, intra- and interassay variation, parallelism) of this assay verify that it is accurate, precise, demonstrates linearity under dilution, and has an appropriate range of sensitivity. Also, the plasma testosterone values we obtained using the EIA procedure are consistent with the ranges of testosterone levels reported for over 100 species of birds, including doves and passerines (Morton et al. 1990, Moore et al. 2002, Garamszegi et al. 2005, Møller et al. 2005). To our knowledge, plasma testosterone levels have not previously been documented in Mourning Doves,
White-eyed Vireos, Red-eyed Vireos, or Indigo Buntings, thus our findings provide valuable reference information.

The EIA procedure we developed is a viable option for researchers interested in measuring testosterone in avian blood samples. This assay is simpler, easier, and requires less time in the laboratory than the Wingfield and Farner (1975) assay because it does not require extraction of testosterone from the plasma samples prior to assay and the components of the EIA are commercially available. In addition, this procedure is useful for investigators who have access to a laboratory with the appropriate equipment (e.g., plate reader) but do not have access to radioactive materials. The Wingfield and Farner (1975) assay, however, is less expensive on a persample basis compared to our assay procedure, and may be advantageous for analyzing a large number of samples.

Combined with a low-volume plasma corticosterone assay procedure (Wingfield et al. 1992, Washburn et al. 2002), researchers could use this assay to measure testosterone and corticosterone from the same individual's small-volume $(30 \mu \mathrm{L})$ blood sample by dividing the sample and running two assay procedures. Alternatively, researchers wishing to obtain values for multiple steroids from the same small-volume plasma sample could utilize an extraction method (e.g., cellulite column) to separate steroids for assay either with our EIA method, the Wingfield and Farner (1975) assay, or another assay procedure that requires such an extraction process (e.g., the EIA described and used with female Darkeyed Juncos [Junco hyemalis] by Clotfelter et al. [2004]). In addition, Deviche and Cortez (2005) validated an enzyme-linked immunosorbent assay for male House Finches (Carpodacus mexicanus) that could be useful for measuring testosterone in other birds with proper validation. 


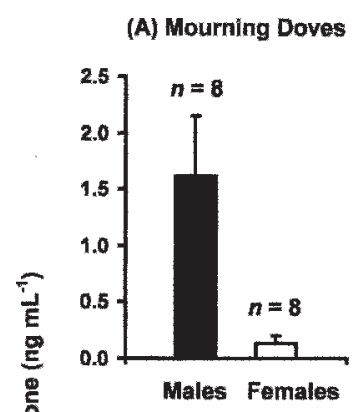

(C) Red-eyed Vireos

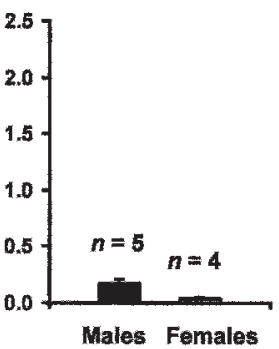

(B) White-eyed Vireos

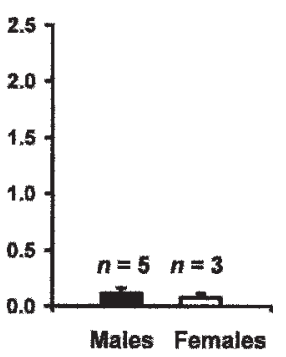

(D) Indigo Buntings

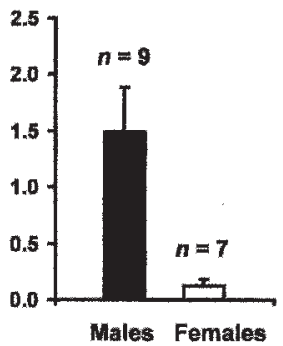

FIGURE 2. Plasma testosterone levels ( $\mathrm{ng} \mathrm{mL}^{-1}$ ) of adult male and adult female free-ranging afterhatching-year (A) wild Mourning Doves in captivity, (B) postbreeding White-eyed Vireos, (C) postbreeding Red-eyed Vireos, and (D) breeding Indigo Buntings. Error bars represent 1 SE. There were six birds (one AHY male and five AHY females) with testosterone levels below the detection limit of the assay. Plasma testosterone levels were higher in male Mourning Doves, Red-eyed Vireos, and Indigo Buntings compared to females of the same species and breeding status, whereas postbreeding male and female White-eyed Vireos had similar plasma testosterone levels.

Breeding captive Mourning Doves (during the normal breeding season), free-ranging postbreeding Red-eyed Vireos, and free-ranging breeding male Indigo Buntings had higher plasma testosterone levels than females of the same species in this study. Low levels of plasma testosterone in females were expected and are consistent with other studies of birds (Cristol and Johnsen 1994, Møller et al. 2005). Numerous recent studies have shown that plasma testosterone levels vary significantly with reproductive state in male birds (Deviche et al. 2000, Moore et al. 2002). The testosterone levels and patterns we observed are consistent with studies of other birds in the same reproductive stage (Wingfield et al. 1987, Morton et al. 1990, Deviche et al. 2000). Plasma testosterone levels were elevated in males during prebreeding and active breeding periods, reproductive stages when males exhibit aggressive behaviors (e.g., territorial defense and mate guarding). Conversely, postbreeding males exhibited less aggressive behaviors (e.g., parental care of fledglings) and had

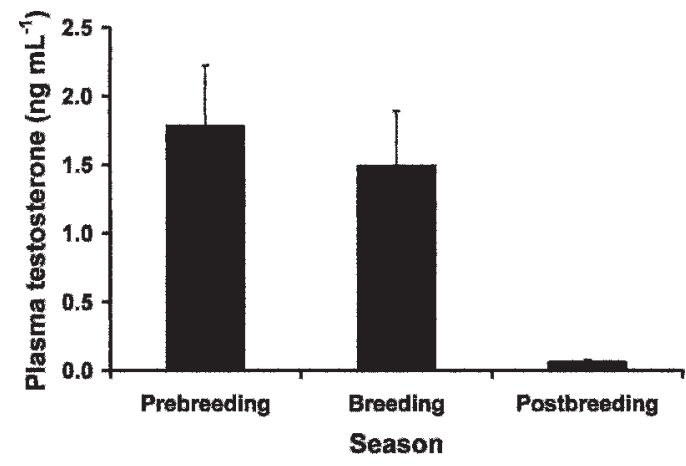

FIGURE 3. Plasma testosterone levels $\left(\mathrm{ng} \mathrm{mL}^{-1}\right)$ of prebreeding, breeding, and postbreeding male after-hatching-year Indigo Buntings. Error bars represent $1 \mathrm{SE}$. There was one postbreeding AHY male with a testosterone level below the detection limit of the assay. Prebreeding and breeding male Indigo Buntings had elevated plasma testosterone levels compared to postbreeding males.

baseline plasma testosterone levels that were similar to those of females. The observed patterns of testosterone levels (e.g., sex-related differences, reproductive stage differences in males) measured by the EIA procedure demonstrate the assay's ability to detect biologically important changes in plasma testosterone in avian blood.

In summary, we validated an enzyme immunoassay procedure that is capable of determining testosterone levels in small-volume avian plasma samples. We tested it on birds that vary in size (13 g to nearly $200 \mathrm{~g}$ ), habitat use (grasslands to mature forests), and migration strategy (with species that travel to the Neotropics and those that winter in Missouri). Biochemical and biological validations with these species showed that this commercially available assay is accurate, precise, and sensitive enough to detect biologically important changes in the gonadal activity of birds during various reproductive stages. This assay procedure has considerable utility for measuring testosterone in avian species, including birds that are very small $(<15 \mathrm{~g})$ and consequently have low blood volumes. Prior to its use in other birds, however, the assay must be validated for each new species, due to potential variation in testosterone levels and plasma chemistry among birds.

Financial and logistical support for this project was provided by the University of Missouri (MU) Division of Biological Sciences, the MU Department of Fisheries and Wildlife Sciences, an MU Life Science Mission Enhancement Postdoctoral Fellowship, an MU Research Board Grant, and the Missouri Department of Conservation (Resource Science Division). Testosterone assays were conducted in the Wildlife Stress Physiology Laboratory in the MU Department of Fisheries and Wildlife Sciences. This research was approved by the University of Missouri Animal Care and Use Committee (Protocols \#3570 and \#3581). 


\section{LITERATURE CITED}

Chandler, C. R., E. D. Ketterson, V. Nolan JR., AND C. ZIEGENFUS. 1994. Effects of testosterone on spatial activity in free-ranging male Darkeyed Juncos (Junco hyemalis). Animal Behaviour 47:1445-1455.

Clotfelter, E. D., D. M. O’Neal, J. M. GauDioso, J. M. CASto, I. M. PARKER-Renga, E. A. SNAJdR, D. L. DUfFy, V. NOlAN JR., AND E. D. Ketterson. 2004. Consequences of elevating plasma testosterone in females of a socially monogamous songbird: evidence of constraints on male evolution? Hormones and Behavior 46:171-178.

Cristol, D. A., AND T. S. Johnsen. 1994. Spring arrival, aggression, and testosterone in female Red-winged Blackbirds (Agelaius phoeniceus). Auk 111:210-214.

Deviche, P., AND L. CoRTez. 2005. Androgen control and immunocompetence in the male House Finch, Carpodacus mexicanus Müller. Journal of Experimental Biology 208:1287-1295.

Deviche, P., J. C. Wingfield, AND P. J. Sharp. 2000. Year-class differences in the reproductive system, plasma prolactin, and corticosterone concentrations, and onset of prebasic molt in male Dark-eyed Juncos (Junco hyemalis) during the breeding period. General and Comparative Endocrinology 118:425-435.

Garamszegi, L. Z., M. Eens, S. HurtrezBoussès, AND A. P. Møller. 2005. Testosterone, testes size, and mating success in birds: a comparative study. Hormones and Behavior 47:389-409.

Graham, L., F. Schwarzenberger, E. Mostl, W. Galama, And A. Savage. 2001. A versatile enzyme immunoassay for the determination of progestogens in feces and serum. Zoo Biology 20:227-236.

Grotjan, H. E., AND B. A. KeEl. 1996. Data interpretation and quality control, p. 51-93. In E. P. Diamandis and T. K. Christopoulos [EDS.], Immunoassay. Academic Press, New York.

Hadley, M. E. 1996. Endocrinology. 4th ed. Prentice-Hall, Upper Saddle River, NJ.

JEFFCOATE, S. L. 1981. Efficiency and effectiveness in the endocrinology laboratory. Academic Press, San Diego, CA.

Ketterson, E. D., V. Nolan JR., M. J. Cawthorn, P. G. PARKer, AND C. Ziegenfus. 1996. Phenotypic engineering: using hormones to explore the mechanistic and functional bases of phenotypic variation in nature. Ibis 138:70-86.

Lee, J. V., C. S. Whaling, B. L. Lasley, and P. MARIER. 1995. Validation of an enzyme immunoassay for measurement of excreted estrogen and testosterone metabolites in the Whitecrowned Sparrow (Zonotrichia leucophrys oriantha). Zoo Biology 14:97-106.

LynN, S. E., B. G. WAlker, AND J. C. WingField. 2005. A phylogenetically controlled test of hypotheses for behavioral insensitivity to testosterone in birds. Hormones and Behavior 47:170-177.
Møller, A. P., L. Z. Garamszegi, D. Gil, S. Hurtrez-Boussès, AND M. EENS. 2005. Correlated evolution of male and female testosterone profiles in birds and its consequences. Behavioral and Ecological Sociobiology 58:534-544.

Mong, T. W., J. H. Schulz, AND J. J. Millspaugh. 2002. Design and construction of Mourning Dove research pens. Transactions of the Missouri Academy of Sciences 36:21-24.

Moore, I. T., N. Perfito, H. WAdA, T. S. Sperry, AND J. C. WingField. 2002. Latitudinal variation in plasma testosterone levels in birds of the genus Zonotrichia. General and Comparative Endocrinology 129:13-19.

Morton, M. L., L. E. Peterson, D. M. Burns, AND N. Allan. 1990. Seasonal and age-related changes in plasma testosterone levels in Mountain White-crowned Sparrows. Condor 92:166-173.

Neter, J., W. Wasserman, And M. H. Kutner. 1990. Applied linear statistical models. 3rd ed. Irwin Press, Boston, MA.

O'Fegan, P. O. 2000. Validation, p. 211-238. In J. P. Gosling [ED.], Immunoassays. Oxford University Press, New York.

Reeves, H. M., A. D. Geis, And F. C. Kniffin. 1968. Mourning Dove capture and banding. Special Scientific Report - Wildlife 117, U.S. Fish and Wildlife Service, Washington, DC.

SAino, N., AND A. P. Møller. 1995. Testosterone correlates of mate guarding, singing, and aggressive behavior in male Barn Swallows, Hirundo rustica. Animal Behavior 49:465-472.

SAS InstituTE. 1990. SAS/STAT user's guide: statistics. Version 6. SAS Institute, Inc., Cary, NC.

SCHWABL, H., AND E. KRINER. 1991. Territorial aggression and song of male European Robin (Erithacus rubecula) in autumn and spring: effects of antiandrogen treatment. Hormones and Behavior 25:180-194.

SILVERIN, B. 1980. The effects of long-acting testosterone treatment of free-living Pied Flycatchers, Ficedula hypoleuca, during the breeding season. Animal Behavior 28:906-912.

Washburn, B. E., D. L. Morris, J. J. Millspaugh, J. FAABORG, AND J. H. Schulz. 2002. Using a commercially available radioimmunoassay to quantify testosterone in avian plasma. Condor 104:558-563.

Wingfield, J. C., G. F. Ball, A. M. Dufty JR., R. E. Hegner, AND M. RAMENOFSKY. 1987. Testosterone and aggression in birds. American Scientist 75:602-608.

Wingfield, J. C., AND D. S. FARner. 1975. The determination of five steroids in avian plasma by radioimmunoassay and competitive protein binding. Steroids 26:311-327.

Wingfield, J. C., C. M. Vleck, And M. C. Moore. 1992. Seasonal changes in the adrenocortical response to stress in birds of the Sonoran Desert. Journal of Experimental Zoology 264: 419-428.

ZAR, J. H. 1996. Biostatistical analysis. 3rd ed. Prentice-Hall, Upper Saddle River, NJ. 